\title{
Assessment of Risk Factors, Treatment and Hospital Stay in Complicated Urinary Tract Infections in Men Caused by Pseudomonas: A Case-Control Study
}

\section{Erkeklerde Pseudomonas ile Gelișen Komplike Üriner Sistem Enfeksiyonlarında Risk Faktörlerinin, Tedavi ve Hastane Yatış Sürelerinin Değerlendirilmesi: Olgu-Kontrol Çalışması}

\author{
Hasan Selçuk Özger', Ömer Karaşahin², Emine Füsun Karaşahin³, Ümmügülsüm Gaygusuz, İlker Şen, Murat Dizbay ${ }^{6}$ \\ ${ }^{1}$ Dr. Ersin Arslan Training and Research Hospital, Clinic of Infectious Diseases, Gaziantep, Turkiye \\ ${ }^{2}$ Erzurum Regional Training and Research Hospital, Clinic of Infectious Diseases, Erzurum, Turkiye \\ ${ }^{3}$ Erzurum Public Health Directorate, Public Health, Erzurum, Turkiye \\ ${ }^{4}$ Erzurum Regional Training and Research Hospital, Intensive Care Unit, Erzurum, Turkiye \\ ${ }^{5}$ Gazi University Faculty of Medicine, Department of Urology, Ankara, Turkiye \\ ${ }^{6}$ Gazi University Faculty of Medicine, Department of Infectious Diseases, Ankara, Turkiye
}

\section{What's known on the subject? and What does the study add?}

It's known that the Pseudomonas, identified as the cause of health care-related complicated urinary tract infection (UTI), is an independent risk factor of mortality. Risk factors and antibiotic resistance data should be known for a proper empiric treatment. Nephrolithiasis and recurrent UTI were found independent risk factors of Pseudomonas related UTI. In such cases, anti-pseudomonal antibiotics should be taken into consideration. When resistance rates are taken into account, ciprofloxacin use should be limited. Also, it's thought that improper empiric treatment would increase costs by prolonging hospitalization.

\begin{abstract}
Objective: It is known that Pseudomonas has been isolated more frequently in health care-related urinary tract infections (UTIs). It was aimed to determine the risk factors and empiric therapies due to antibiotic resistance in Pseudomonas-related male UTIs, and assess the effect of Pseudomonas isolation on treatment and length of hospital stay.

Materials and Methods: The study was conducted between January 2011 and January 2013 with 228 male health care-related complicated UTI patients hospitalized in the Urology and Infectious Diseases Inpatient Clinics at Gazi University Faculty of Medicine. Three hundred UTI attacks in 228 patients were evaluated retrospectively with regard to agents.

Results: Pseudomonas was isolated in 37 of 300 complicated UTI attacks in 228 male patients. Nephrolithiasis, recurrent UTI and internal urinary catheterization were determined as the risk factors for Pseudomonas related with health care-related UTI. It was understood that nephrolithiasis increased Pseudomonas isolated UTI risk 3.5 fold and recurrent UTI increased the risk 8.9 fold. The antibiotic resistance of Pseudomonas was higher than other agents. Pseudomonas related UTIs prolonged the duration of hospital stay and antibiotic treatment.

Conclusion: In the presence of nephrolithiasis, recurrent UTI and internal urinary catheterization, drugs against Pseudomonas would be appropriate empiric treatment for health care-related complicated UTI. Ciprofloxacin use should be restricted when local antibiotic resistance, which leads empiric treatment, is taken into consideration. Increases in hospital stay and antibiotic treatment duration were thought to be associated with recurrent infection frequency and high antibiotics resistance in Pseudomonas related UTIs.
\end{abstract}

Keywords: Pseudomonas, complicated urinary tract infection, drug resistance

Correspondence: Ömer Karaşahin MD, Erzurum Regional Training and Research Hospital, Clinic of Infectious Diseases, Erzurum, Turkiye Phone: +90 5536604831 E-mail: mrkrshn@hotmail.com

Received: 09.10.2016 Accepted: 21.12.2016

Presented in: European Society Clinical Microbiology Infectious Diseases (ESCMID), 10 May 2014, in Barcelona, Spain.

Cite this article as: Özger HS, Karaşahin Ö, Karaşahin EF, Gaygusuz Ü, Şen İ, Dizbay M. Assessment of Risk Factors, Treatment and Hospital Stay in Complicated Urinary Tract Infections in Men Caused by Pseudomonas: A Case-Control Study. J Urol Surg 2017;4:48-52.

๑Copyright 2017 by the Association of Urological Surgery / Journal of Urological Surgery published by Galenos Publishing House. 


\section{Öz}

Amaç: Sağlık bakımı ilişkili üriner sistem enfeksiyonlarında (ÜSE), Pseudomonas'ın artan sıklıklarda izole edildiği bilinmektedir. Bu çalışmada, erkeklerde Pseudomonas ilişkili komplike ÜSE'de risk faktörlerinin saptanması, antibiyotik dirençleri değerlendirilerek ampirik tedavi yaklaşımlarının belirlenmesi ile Pseudomonas izolasyonunun tedavi ve hastane yatış süresi üzerine etkisinin değerlendirilmesi amaçlanmaktadır.

Gereç ve Yöntem: Çalışmaya Ocak 2011-Ocak 2013 tarihleri arasında Gazi Üniversitesi Tıp Fakültesi, Üroloji ve Enfeksiyon Hastalıkları Servisleri'nde sağlık bakımı ilişkili komplike ÜSE tanısı konulan 228 erkek hasta dahil edilmiştir. Dahil edilen 228 hastada 300 ÜSE atağı izole edilen etkenler açısından retrospektif değerlendirilmiştir.

Bulgular: İki yüz yirmi sekiz erkek hastada 300 komplike ÜSE atağının 37'sinde Pseudomonas izole edilmiştir. Pseudomonas ilişkili sağlık bakımı ilişkili komplike ÜSE için nefrolitiyazis, rekürren ÜSE ve internal üriner kateterizasyon risk faktörleri olarak tespit edilmiştir. Nefrolitiyazis varlığında 3,5 kat, rekürren ÜSE varlığında ise 8,9 kat riskin arttığı saptanmıştır. Pseudomonaslarda antibiyotik direncinin diğer suşlara göre daha yüksek olduğu belirlenmiştir. Pseudomonas etken olduğu ÜSE'lerin hastane yatış süreleri ve antibiyotik tedavi sürelerini uzattığı saptanmıştır.

Sonuç: Sağlık bakımı ilişkili komplike ÜSE ampirik tedavisinde, nefrolitiyazis, internal üriner kateterizasyon ve rekürren ÜSE risk faktörleri varlığında Pseudomonas'a yönelik tedavinin uygun olacağı düşünülmektedir. Ampirik tedaviye yön verecek lokal antibiyotik direnç verileri göz önüne alındığında siprofloksasin kullanımın sınırlandırılması öngörülmektedir. Pseudomonas ilişkili ÜSE'lerde hastanede yatış süresi ve antibiyotik kullanım sürelerindeki artışın rekürren enfeksiyon sıklığı ve yüksek antibiyotik direnci ile ilişkili olduğu düşünülmektedir.

Anahtar Kelimeler: Pseudomonas, komplike üriner sistem enfeksiyonu, ilaç direnci

\section{Introduction}

Urinary tract infections (UTIs) constitute more than 30\% of the nosocomial infections (1). Besides causing prolonging of hospital stay and increase in health expenditures, it also leads to bacteremia and mortality in case of improper empiric therapy (2). Therefore, it is important to determine agents early and start proper empiric therapy as soon as possible. Differentiation of increasing antibiotic resistances due to the agents requires risk factors of possible agents to be evaluated before therapy. Existence of urinary catheter, history of urological intervention, long hospital stay, male sex and existence of disease causing debility are risk factors for nosocomial UTI development (3). Especially in recent years, non-fermenter bacteria including Pseudomonas strains have an extensive place in health carerelated infections (4).

It was aimed to determine the risk factors and empiric therapies due to the antibiotic resistance in Pseudomonas related male UTIs, and assess the effect of Pseudomonas isolation on treatment and length of hospital stay.

\section{Materials and Methods}

The study was conducted between January 2011 and January 2013 with 228 male health care-related complicated UTI patients hospitalized in our urology and infectious diseases inpatient clinics. Three hundred UTI attacks in 228 patients were evaluated retrospectively with regard to agents. UTIs were grouped as Pseudomonas spp. isolated and not and compared for the risk factors, hospital stay and treatment duration.

\section{Statistical Analysis}

Data was presented as number and percentage and continuous variables were presented by mean \pm standard deviation and median (minimum, maximum). Chi-square test was used for comparisons. Logistic regression analysis was conducted with nephrolithiasis, recurrent UTI, prostatic hypertrophy, diabetes mellitus, internal and external catheter which were determined as risk factors. Antibiotic resistance of most identified agents were determined and presented as number and percentage.

Double J catheter use was accepted as internal catheterization and other urinary catheterization ways except double J catheter accepted as external catheterization.

\section{Results}

Three hundred complicated UTI attacks in 228 male patients were included. The mean age of the patients was $65.7 \pm 15.18$ years (median $69 ; 18-94)$. There was no statistically significant difference between the Pseudomonas isolated and non-isolated patient groups $(67 \pm 14.9$ vs. $69 \pm 15.2 ; p=0.37)$.

Pseudomonas was isolated in 37 of 300 UTI attacks. Isolated agents are presented in Table 1.

Table 1. Distribution of agents in urinary tract infections

\begin{tabular}{lll}
\hline Agent & $\mathbf{n = 3 0 0}$ & $\%$ \\
\hline Pseudomonas spp. & 37 & 12.3 \\
Acinetobacter spp. & 5 & 1.6 \\
Candida spp. & 17 & 5.6 \\
Citrobacter freundi & 1 & 0.3 \\
Corynebacterium jeikeium & 1 & 0.3 \\
Escherichia coli & 154 & 51.3 \\
Enterococcus spp. & 22 & 7.3 \\
Klebsiella spp. & 35 & 11.6 \\
Coagulase negative Staphylococcus & 26 & 8.6 \\
Stenotrophomonas maltophilia & 2 & 0.6 \\
\hline
\end{tabular}


UTI attacks grouped as Pseudomonas isolated and not, compared for the complicated UTI risk factors and are presented in Table 2.

According to the result of logistic regression analysis, it was found that recurrent UTI increased complicated UTI risk 2.97 (95\% confidence interval: $1.45-6.09)$ fold $(p=0.003)$.

Antibiotic resistances of most common isolated agents (Escherichia coli, Pseudomonas and Klebsiella) were determined. Ciprofloxacin resistance was $72 \%$ and $51.4 \%$ in Escherichia coli and Klebsiella isolates, respectively. Trimethoprimsulfamethoxazole resistance was 59\% and 60\%; extendedspectrum beta-lactamase (ESBL) positivity was 48\% and 45.7\%, respectively. Antibiotic resistance of Pseudomonas isolates are shown in Table 3.

UTI attacks grouped as Pseudomonas isolated and not, compared for length of hospital stay and antibiotic treatment duration (Table 4).

\section{Discussion}

Pseudomonas is one of the most common agents determined in complicated UTIs related with gram negative enteric bacteria and especially more often determined in health care-related UTIs $(1,2,5,6,7)$. A study assessing the differentiation of UTI

Table 2. Distribution of complicated urinary tract infection risk factors by agents

\begin{tabular}{|c|c|c|c|}
\hline & Pseudomonas isolated (\%) & Non-Pseudomonas agents isolated & $\mathbf{p}$ \\
\hline \multicolumn{4}{|c|}{ Urinary tract malignancy } \\
\hline Yes & $17(45.9)$ & $98(37.3)$ & \multirow[b]{2}{*}{0.30} \\
\hline No & $20(54.1)$ & $165(62.7)$ & \\
\hline \multicolumn{4}{|c|}{ Diabetes mellitus } \\
\hline Yes & 7 (18.9) & $63(23.9)$ & \multirow[b]{2}{*}{0.65} \\
\hline No & $30(81.1)$ & $200(76.1)$ & \\
\hline \multicolumn{4}{|c|}{ Internal urinary catheterization } \\
\hline Yes & $9(24.3)$ & $32(12.1)$ & \multirow[t]{2}{*}{$<0.05$} \\
\hline No & $28(75.7)$ & $231(87.9)$ & \\
\hline \multicolumn{4}{|c|}{ External urinary catheterization } \\
\hline Yes & $9(24.3)$ & $89(33.9)$ & \multirow[b]{2}{*}{0.24} \\
\hline No & $28(75.7)$ & $174(66.1)$ & \\
\hline \multicolumn{4}{|c|}{ Prostatic hypertrophy } \\
\hline Yes & 16 (43.2) & $132(50.1)$ & \multirow[b]{2}{*}{0.42} \\
\hline No & $21(56.8)$ & $131(49.9)$ & \\
\hline \multicolumn{4}{|c|}{ Nephrolithiasis } \\
\hline Yes & $11(29.8)$ & $37(14.0)$ & \multirow[b]{2}{*}{$<0.05$} \\
\hline No & $26(70.2)$ & $226(86.0)$ & \\
\hline \multicolumn{4}{|c|}{ Urological intervention } \\
\hline Yes & $19(51.3)$ & $147(55.9)$ & \multirow[b]{2}{*}{0.60} \\
\hline No & $18(48.6)$ & $116(44.1)$ & \\
\hline \multicolumn{4}{|c|}{ Recurrent urinary tract infection } \\
\hline Yes & $22(59.4)$ & $82(31.2)$ & \multirow[b]{2}{*}{$<0.05$} \\
\hline No & $15(40.6)$ & $181(68.8)$ & \\
\hline \multicolumn{4}{|c|}{ Two and more attacks } \\
\hline Yes & 14 (37.9) & 49 (18.6) & \multirow[b]{2}{*}{$<0.05$} \\
\hline No & $23(62.1)$ & 214 (81.4) & \\
\hline \multicolumn{4}{|c|}{ Neurogenic bladder } \\
\hline Yes & $3(8.1)$ & $10(3.9)$ & \multirow[b]{2}{*}{0.41} \\
\hline No & 34 (91.9) & $253(96.1)$ & \\
\hline
\end{tabular}


Table 3. Antibiotic resistance of Pseudomonas isolates

\begin{tabular}{lll}
\hline Antibiotic & Resistance (n) & (\%) \\
\hline Ciprofloxacin & 24 & 64.8 \\
Cefepime & 19 & 51.3 \\
Ceftazidime & 12 & 32.4 \\
Cefoperazone-sulbactam & 17 & 45.9 \\
Piperacillin-tazobactam & 7 & 18.9 \\
Aminoglycoside & 7 & 18.9 \\
Carbapenem & 5 & 13.5 \\
\hline
\end{tabular}

Table 4. Comparison of hospital stay and treatment duration in urinary tract infection attacks by agents

\begin{tabular}{llll}
\hline & $\begin{array}{l}\text { Pseudomonas } \\
\text { UTI }\end{array}$ & $\begin{array}{l}\text { Non- } \\
\text { Pseudomonas } \\
\text { UTI }\end{array}$ & $\mathbf{p}$ \\
\hline Therapy duration (day) & $14 \pm 5.5$ & $10 \pm 3.5$ & $<0.05$ \\
$\begin{array}{l}\text { Hospital stay duration } \\
\text { (day) }\end{array}$ & $14 \pm 8.8$ & $10 \pm 8.0$ & $<0.05$ \\
\hline UTI: Urinary tract infection & & & \\
\hline
\end{tabular}

agents at intensive care units (ICUs) over a 10-year period showed a significant increase in UTIs caused by Pseudomonas and Klebsiella isolates (8).

Determining the risk factors for UTI agents is very important to predict the real agent and start treatment with proper empiric antibiotic therapy (1). Djordjevic et al. (9) identified female gender, previous hospitalization and beta-lactam antibiotic use as independent risk factors for UTIs caused by Pseudomonas. Venier et al. (10) found that Pseudomonas UTIs in ICU patients were associated with male gender, length of hospital stay and antibiotic therapy. A study assessing UTIs developed in males showed that the frequency of Pseudomonas originated from UTIs increase with age (11). Urinary stone and catheter were found to be risk factor for Pseudomonas related UTI by Johansen et al. (12). Association of bacteria except Escherichia coli with recurrent UTIs in male gender was proven in a study by Amna et al. (13) assessing community-acquired bacteriuria. A study assessing recurrent UTIs after renal transplantation found that the most common identified agent was multi-drug resistant Pseudomonas after ESBL-positive Klebsiella and ESBL-negative Escherichia colistrains (14). In accordance with the literature, our study proved that anti-pseudomonal antibiotics should be used in empiric treatment of health care-related complicated UTIs when there are risk factors such as nephrolithiasis and recurrent UTI.

Phenotypic characteristics of Pseudomonas such as pyoverdin, protease, and phospholipase A production in combination with quorum sensing activity and biofilm formation were revealed to ease the development of catheter related UTIs (15). In our study, internal catheter (double J catheter) presence was found to be more frequent in Pseudomonas related UTI.
Antibiotic resistance in Pseudomonas was declared to be higher than other strains in UTIs (8). In our study, ciprofloxacin resistance was detected quite high in Pseudomonas strains and it was observed that the oral therapy chance decreased gradually. Resistance to phosphomycine which can be used in oral therapy was found in 56\% of Pseudomonas strains in Turkey (16). Fu et al. (17) showed that there was 30-40\% resistance to parenteral administrable anti-pseudomonal antibiotics. In our study, frequency of anti-pseudomonal cephalosporin resistance in Pseudomonas strains was detected to be $30 \%$ and higher. Also, it is known that carbapenem resistance is increasing gradually. Carbapenem resistance in Pseudomonas strains in invasive devicerelated infections was determined as $42 \%, 4 \%$ in a study conducted in 43 countries from Latin America, Asia, Africa and Europe (18). In our study, carbapenem resistance was $13 \%$ in Pseudomonas which caused UTIs. Especially, a rise in recurrent infections associated with Pseudomonas causes a rise in frequency of antibiotic therapy, thereby, it easies the development of antibiotic resistance. The frequency of multi-drug resistant Pseudomonas aeruginosa in UTI was shown to be increased in half between 2000 and 2009 by Zilberberg and Shorr (19). Clinical guidelines indicate that optimal therapy should be given according to the clinical evaluations and local antibiotic resistance data, because of the differences in data regarding resistance $(20,21)$. Increases in length of hospital stay and antibiotic treatment duration were thought to be associated with recurrent infection frequency and high antibiotics resistance in Pseudomonas related UTIs.

Frequency of recurrent infection and increase in drug resistance of Pseudomonas chains make the infection treatment difficult. A study made in India showed that Pseudomonas related nosocomial UTIs increased the hospital stay duration (21). In our study, antibiotic therapy and hospital stay duration in Pseudomonas isolated UTIs were found to be higher than in UTIs originated from other agents.

Horino et al. (22) showed that the important part of the Pseudomonas bacteremia was secondary to UTI derived from the same bacteria. Moreover, improper empiric antibiotic therapy in UTI attacks was shown to be associated with bacteremia and mortality (2).

\section{Study Limitations}

The most favorable limitation of our work is retrospective construct. It is also thought that increasing the number of agents in order to determine the risk factors for complicated UTI associated with Pseudomonas in men will increase the power of future studies. 


\section{Conclusion}

Empiric treatment should be started after assessing the risk factors of health care-related complicated UTI. Improper empiric antibiotic selection without consideration of risk factors and local resistance data in Pseudomonas related UTI especially, is thought to be the reason of recurrence and increase in resistance. Anti-pseudomonal antibiotics should be used as empiric treatment in the presence of nephrolithiasis, recurrent UTI and internal urinary catheter. However, when the resistance rates are taken into account, ciprofloxacin use should be limited. In addition, it is thought that improper empiric treatment would increase health care-related costs by prolonging hospitalization.

\section{Ethics}

Ethics Committee Approval: The study was retrospectively reviewed by examining patient files. For this reason, ethical approval was not received.

Informed Consent: Retrospective study.

Peer-review: Externally peer-reviewed.

\section{Authorship Contributions}

Surgical and Medical Practices: H.S.Ö., Ö.K., Ü.G., Concept: H.S.Ö., Ö.K., E.F.K., Ü.G., I.Ş., M.D., Design: H.S.Ö., Ö.K., M.D., Data Collection or Processing: H.S.Ö., Ö.K., E.F.K., Ü.G., Analysis or Interpretation: E.F.K., Literature Search: H.S.Ö., Ö.K., E.F.K., Ü.G., I.Ş., M.D., Writing: H.S.Ö., Ö.K., E.F.K., Ü.G., I.Ş., M.D.

Conflict of Interest: No conflict of interest was declared by the authors.

Financial Disclosure: The authors declared that this study received no financial support.

\section{References}

1. Oh WS, Hur JA, Kim ES, Park KH, Choi HK, Moon C, Kim BN. Factors associated with specific uropathogens in catheter-associated urinary tract infection: developing a clinical prediction model. J Int Med Res 2014;42:1335-1347.

2. Ortega M, Marco F, Soriano A, Almela M, Martinez JA, Pitart C, Mensa J. Epidemiology and prognostic determinants of bacteraemic catheter-acquired urinary tract infection in a single institution from 1991 to 2010. J Infect 2013;67:282-287.

3. lakovlev SV, Suvorova MP, Kolendo SE, Burmistrova EN, Sergeeva EV, Cherkasova NA, Eremina LV. [Clinical efficacy of the antimicrobial drug furamag in nosocomial urinary tract infections]. Ter Arkh 2014;86:65-72.

4. Corvec S, Poirel L, Espaze E, Giraudeau C, Drugeon H, Nordmann P. Long-term evolution of a nosocomial outbreak of Pseudomonas aeruginosa producing VIM-2 metallo-enzyme. J Hosp Infect 2008;68:73-82.

5. Horcajada JP, Shaw E, Padilla B, Pintado V, Calbo E, Benito N, Gamallo R, Gozalo M, Rodríguez-Bano J; ITUBRAS group; Grupo de Estudio de Infección Hospitalaria (GEIH); Sociedad Española de Enfermedades Infecciosas y Microbiología Clínica (SEIMC). Healthcare-associated, community-acquired and hospital-acquired bacteraemic urinary tract infections in hospitalized patients: a prospective multicentre cohort study in the era of antimicrobial resistance. Clin Microbiol Infect 2013;19:962-968.

6. Aguilar-Duran S, Horcajada JP, Sorli L, Montero M, Salvado M, Grau S, Gomez $J$, Knobel $\mathrm{H}$. Community-onset healthcare-related urinary tract infections: comparison with community and hospital-acquired urinary tract infections. J Infect 2012;64:478-483.
7. Medina-Polo J, Jimenez-Alcaide E, Garcia-Gonzalez L, Guerrero-Ramos F, PerezCadavid S, Arrebola-Pajares A, Sopena-Sutil R, Benitez-Salas R, Diaz-Gonzalez R, Tejido-Sanchez A. Healthcare-associated infections in a department of urology: incidence and patterns of antibiotic resistance. Scand J Urol 2014;48:203-209.

8. Yoon BI, Kim HS, Kim SD, Cho KJ, Kim SW, Ha US, Cho YH, Sohn DW. Changes in bacterial species and antibiotic sensitivity in intensive care unit: acquired urinary tract infection during 10 years interval (2001-2011). Urol J 2014;11:1478-1484.

9. Djordjevic Z, Folic MM, Zivic Z, Markovic V, Jankovic SM. Nosocomial urinary tract infections caused by Pseudomonas aeruginosa and Acinetobacter species: Sensitivity to antibiotics and risk factors. Am J Infect Control 2013;41:1182-1187.

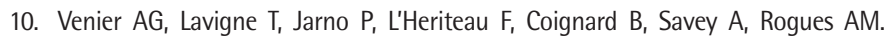
Nosocomial urinary tract infection in the intensive care unit: when should Pseudomonas aeruginosa be suspected? Experience of the French national surveillance of nosocomial infections in the intensive care unit, Rea-Raisin. Clin Microbiol Infect 2012;18:E13-15.

11. Koeijers JJ, Verbon A, Kessels AG, Bartelds A, Donkers G, Nys S, Stobberingh EE. Urinary tract infection in male general practice patients: uropathogens and antibiotic susceptibility. Urology 2010;76:336-340.

12. Johansen TE, Cek M, Naber KG, Stratchounski L, Svendsen MV, Tenke P; PEP and PEAP-study investigators; Board of the European Society of Infections in Urology. Hospital acquired urinary tract infections in urology departments: pathogens, susceptibility and use of antibiotics. Data from the PEP and PEAP-studies. Int J Antimicrob Agents 2006;28(Suppl 1):S91-107.

13. Amna MA, Chazan B, Raz R, Edelstein H, Colodner R. Risk factors for nonEscherichia coli community-acquired bacteriuria. Infection 2013;41:473-477.

14. Bodro M, Sanclemente G, Lipperheide I, Allali M, Marco F, Bosch J, Cofan F, Ricart MJ, Esforzado N, Oppenheimer F, Moreno A, Cervera C. Impact of antibiotic resistance on the development of recurrent and relapsing symptomatic urinary tract infection in kidney recipients. Am J Transplant 2015;15:1021-1027.

15. Tielen $P$, Narten $M$, Rosin N, Biegler I, Haddad I, Hogardt M, Neubauer R, Schobert M, Wiehlmann L, Jahn D. Genotypic and phenotypic characterization of Pseudomonas aeruginosa isolates from urinary tract infections. Int J Med Microbiol 2011;301:282-292.

16. Demir T, BuyukgucluT. Evaluation of the in vitro activity of fosfomycin tromethamine against Gram-negative bacterial strains recovered from community- and hospitalacquired urinary tract infections in Turkey. Int J Infect Dis 2013;17:e966-970.

17. Fu $X H$, Zhou $W$, Zhang $X M$, Yin $Y B$, Jing $C M$, Liu $L$, Zhao J. [Clinical analysis of 22 cases community-acquired Pseudomonas aeruginosa urinary tract infection] Zhonghua Er Ke Za Zhi 2013;51:298-301.

18. Rosenthal VD, Maki DG, Mehta $Y$, Leblebicioglu H, Memish ZA, Al-Mousa $\mathrm{HH}_{\text {, }}$ Balkhy H, Hu B, Alvarez-Moreno C, Medeiros EA, Apisarnthanarak A, Raka L, Cuellar LE, Ahmed A, Navoa-Ng JA, El-Kholy AA, Kanj SS, Bat-Erdene I, Duszynska W, Van Truong N, Pazmino LN, See-Lum LC, Fernández-Hidalgo R, Di-Silvestre G, Zand F, Hlinkova S, Belskiy V, Al-Rahma H, Luque-Torres MT, Bayraktar N, Mitrev Z, Gurskis V, Fisher D, Abu-Khader IB, Berechid K, Rodriguez-Sánchez A, Horhat FG, RequejoPino 0, Hadjieva N, Ben-Jaballah N, Garcia-Mayorca E, Kushner-Dávalos L, Pasic S, Pedrozo-Ortiz LE, Apostolopoulou E, Mejia N, Gamar-Elanbya MO, Jayatilleke K, de Lourdes-Dueñas M, Aguirre-Avalos G; International Nosocomial Infection Control Consortium. International Nosocomial Infection Control Consortium (INICC) report, data summary of 43 countries for 2007-2012. Device-associated module. Am J Infect Control 2014;42:942-956.

19. Zilberberg MD, Shorr AF. Secular trends in gram-negative resistance among urinary tract infection hospitalizations in the United States, 2000-2009. Infect Control Hosp Epidemiol 2013;34:940-946.

20. Hooton TM, Bradley SF, Cardenas DD, Colgan R, Geerlings SE, Rice JC, Saint $S$, Schaeffer AJ, Tambayh PA, Tenke P, Nicolle LE; Infectious Diseases Society of America. Diagnosis, prevention, and treatment of catheter-associated urinary tract infection in adults: 2009 International Clinical Practice Guidelines from the Infectious Diseases Society of America. Clin Infect Dis 2010;50:625-663.

21. Tenke P, Bjerklund Johansen TE, Matsumoto T, Tambyah PA, Naber KG; European Urologist Association, Urologist Association of Asia. [European and Asian guidelines on management and prevention of catheter-associated urinary tract infections]. Urologiia 2008:84-91.

22. Horino T, Chiba A, Kawano S, Kato T, Sato F, Maruyama Y, Nakazawa Y, Yoshikawa K, Yoshida M, Hori S. Clinical characteristics and risk factors for mortality in patients with bacteremia caused by Pseudomonas aeruginosa. Intern Med 2012;51:59-64. 